\title{
UNCERTAINTY MODELING USING INTUITIONISTIC FUZZY NUMBERS
}

\author{
Vladimir R. Milovanovića , Aleksandar V. Aleksićb, \\ Vlada S. Sokolovićc, Marjan A. Milenkov ${ }^{\mathrm{d}}$ \\ a University of Defence in Belgrade, Military Academy, \\ Department for Logistics, Belgrade, Republic of Serbia, \\ e-mail: vaci84milovanovic@gmail.com, corresponding author, \\ ORCID iD: (1)https://orcid.org/0000-0002-5109-4321 \\ ${ }^{b}$ University of Kragujevac, Faculty of Engineering Science, \\ Department for Production Machinery, Kragujevac, Republic of Serbia, \\ e-mail: aaleksic@kg.ac.rs, \\ ORCID iD: (Dhttps://orcid.org/0000-0002-7990-9123 \\ ${ }^{c}$ University of Defence in Belgrade, Military Academy, \\ Department for Logistics, Belgrade, Republic of Serbia, \\ e-mail: vlada.sokolovic@va.mod.gov.rs, \\ ORCID iD: Dhttps://orcid.org/0000-0003-0782-0506 \\ d University of Defence in Belgrade, Military Academy, \\ Department for Logistics, Belgrade, Republic of Serbia, \\ e-mail: marjan.milenkov@va.mod.gov.rs, \\ ORCID iD: (i)https://orcid.org/0000-0003-2054-0525
}

DOI: 10.5937/vojtehg69-33301; https://doi.org/10.5937/vojtehg69-33301

FIELD: Industrial engineering, Engineering management ARTICLE TYPE: Original scientific paper

\begin{abstract}
:
Introduction/purpose: The paper discusses the selection of the most optimal supplier using the example of an unmanned aircraft when the decision maker has data of a qualitative nature. Problems that arise in practice in the selection of suppliers relate to the selection of adequate criteria as well as the way they are evaluated by the decision maker. One of the ways of assessing the criteria of a qualitative character is the usage of linguistic expressions, which gives decision makers the freedom to express their position and opinion through descriptive assessments. This method of assessment is not the most accurate and can introduce a certain amount of uncertainty for the decision maker.
\end{abstract}

ACKNOWLEDGMENT: The work stemmed from the project Model of Logistics Support Planning Support System (VA-TT-1 / 20-22). 
Methods: To solve the problem of uncertainty, the paper proposes a method of modeling data using intuitive fuzzy numbers. Intuitive fuzzy numbers are suitable for solving the problem of uncertainty in situations when it is necessary to review safety during the assessment. To rank suppliers, the ELECTRE method is used, which is adapted to intuitive fuzzy numbers (IF ELECTRE). The IF ELECTRE method was chosen because it clearly presents the potential of all suppliers, i.e. their advantages and disadvantages in relation to the required criteria.

Results: Using IF ELECTRE, the final results provide a shape of mutual preference or indifference between suppliers. The ranking clearly shows the potential of all suppliers, which in a future procurement can serve as a reference for decision making.

Conclusion: The contribution of this paper is reflected in the proposed model that can be used in practice to solve not only the problem of supplier selection, but also similar problems where the decision is made based on inaccurate data. Using these models seeks to reduce indecision and subjectivity in decision making.

Key words: fuzzy logic, fuzzy set, intuitionistic fuzzy set, IF ELECTRE method.

\section{Introduction}

Making decisions based on a large number of different data and information is a complex and demanding process. The decision-making process is further complicated when different views and opinions of experts are included in it or incomplete information about the decisionmaking problem is available. In order to overcome the problems of uncertainty, subjectivity and uncertainty, the theory of fuzzy logic is developed Lotfi Zadeh (Zadeh, 1965; Zadeh, 1975a; Zadeh, 1975b). The fuzzy logic theory has proven useful in complex systems where there is uncertainty about the input data needed to make certain decisions as well as in situations when a decision is made based on experience, intuition and subjective assessment of parameters by the decision maker. Initially, logic was applied mainly in engineering with the aim of solving various practical engineering problems, but so far it has evolved and found its application in areas such as artificial intelligence (Pokorni, 2021) and (Milošević et al, 2021).

The fuzzy approach to solve a problem provides simple and clear linguistic qualifications that describe the problem more relevantly. One of the methods most commonly used to model linguistic qualifications is various types of fuzzy numbers: type 1 (Dubois \& Prade, 1978; Dubois \& Prade, 1979) and (Zimmermann, 1996), type 2 (Mendel, 2003), Z- 
numbers (Zadeh, 2011), rough numbers (Zheng et al, 2019), and intuitive fuzzy numbers (Atanassov, 1983; Atanassov, 1986). The shapes of the mentioned fuzzy numbers are most often triangular and trapezoidal, and one can also find the shapes of parabolas, logistic curves, etc. Another way to model inaccurate data is to use intervals. The interval is defined by decision makers where they allocate linguistic qualifications to a specific domain.

Problems that often occur in practice are problems of choosing the most favorable option. Whether it is a problem related to a process, activity or task, the decision maker makes judgments and decisions based on the available data. By the nature of the decision that is made, it contains a subjective attitude and opinion, regardless of whether the decision maker is biased or not in one of the offered options.

The motivation for the research stemmed from the need to minimize or eradicate the problems that occur when choosing the most optimal supplier. The most common problems that can be noticed when choosing a supplier are: wrongly chosen criteria and the presence of uncertainty or hesitation in evaluating the alternative by criteria. Wrongly chosen criteria can lead a decision maker in the wrong direction, which can result in a high ranking of a supplier who does not have the potential to meet all defined requirements. The presence of uncertainty and uncertainty in the assessment is very difficult to remove, but in some way a solution to this problem must be found.

A novelty in this paper is the definition of criteria for the procurement of an unmanned aircraft from the point of view of military logistic support, as well as the use of the IF ELECTRE method to model the uncertainty of data that occur during the procurement of armament.

Therefore, the aim of this paper is to propose adequate criteria to be considered for the procurement of unmanned aircraft, as well as for finding ways to model and minimize uncertainty in decision making, based on the example of choosing a supplier for unmanned aircraft.

To meet this goal, the research questions to be answered in this paper are: What criteria to choose as the most appropriate for the selection of suppliers of unmanned aircraft, how to model inaccurate and unclear data, how to reduce uncertainty and hesitation in decision making, as well as which method to use to rank suppliers without seeing a clear picture of the preferences of all suppliers?

The topic - the choice of suppliers - has been important lately. A large number of published papers deal with it using the fuzzy approach to model uncertainty, while the most common methods of multicriteria decision making are used for ranking. Hence the need to define 
adequate criteria, with price not being the main and decisive factor, as in most other cases. So in this case, price does not play such an important role although it is in correlation with all the criteria. Nowadays, unmanned aerial vehicles are widely used for various military tasks, so it is necessary to look at the criteria from the point of view of logistical support.

In order to apply the mentioned methods of uncertainty modeling as well as to make a decision on the most favorable option, the paper analyzes the basics settings and algorithms of intuitive fuzzy numbers and fuzzy Electre methods. Based on an example in practice, the solution of the problem of choosing the most favorable supplier of unmanned aircraft is presented. The selection is realized by evaluating all options (alternatives) in linguistic terms based on defined criteria, which are of a qualitative nature. Linguistic expressions are modeled by intuitive fuzzy numbers whose domain is defined in the interval from 0 to 1 .

\section{Literature review}

Bearing in mind that the aim of the paper is to model uncertainty using intuitive fuzzy numbers, as well as to use the ELECTRE method extended by intuitive fuzzy approach (IF ELECTRE) to rank suppliers, this section of the paper presents a review of the literature.

The creator of intuitive fuzzy numbers is the researcher Atanassov, who defined the fuzzy set and presented the mathematical apparatus. By analyzing the literature, one can find a large number of papers where intuitive fuzzy numbers were used. For modeling uncertainty using intuitive fuzzy numbers, the idea was found by analyzing a large number of papers where the results applied in practice justified the expectations of the authors. Choosing a dream home (Shureshjani, 2021) used the Best-Worst method extended with intuitive fuzzy numbers to make a decision with a large number of criteria, because the input data was unclear since decision makers were uncertain when evaluating alternatives. To purchase a smartphone (Arunodaya et al, 2020), he used an intuitive fuzzy approach combined with the MABAC method. Due to the impact of the COVID-19 pandemic on the agile choice of external suppliers of appliances (Goker, 2021), a model for outsourcing performance identification has been developed. By applying the intuitive fuzzy approach, the need for more agile providers was solved. The influence of the unclear numbers on the final results is presented using the example of risk assessment in construction projects (Šmidovnik \& Grošelj, 2021). In addition to the above analyzes of the application of the 
intuitive fuzzy approach, there are a number of papers from which the following solutions to the problem stand out: slow supply in the supply chain (Tavana et al, 2016), energy security assessment (Alipour et al, 2018), supplier selection (Kaur, 2014), selection of computer performance (Nirmala \& Uthra, 2017), job selection for investing money (Zeng et al, 2014), selection of a nuclear power plant site (Das et al, 2017), and risk analysis of changes in industry (Kushwaha et al, 2020).

There are a number of methods and approaches for ranking alternatives. This paper uses a multi-criteria model of Electre (Elimination and Choice Translating Reality) developed by Bernard Roy and Bouyssou (Roy \& Bouyssou, 1986) with their collaborators. In the literature review so far, the method of intuitive fuzzy ELECTRE (IF ELECTRE) has been used in a large number of studies that have solved certain problems related most often to comparing options and understanding the advantages of one option over another. Rouyendegh (2018) preferred intuitive fuzzy numbers over ordinary fuzzy numbers due to the complexity of problem solving as well as the indecision of decision makers in assigning values to the considered alternatives. Also, the original ELECTRE method cannot be efficiently managed due to the lack of precise data, so it is necessary to use the IF ELECTRE method. Rogulj and Kilić Pamuković (Rogulj et al, 2021) used IF ELECTRE to support decision makers in the process of managing the project of removing construction barriers for schools with children with disabilities. They chose this method because the results of applying the model clearly reflected the difference in the annihilated options. Also, it was used for the selection of suppliers of raw materials (Komsiyah et al, 2019), for the evaluation of the criteria of public transport projects (Jacek \& Kruszyński, 2015), for the selection of the best project (Rouyendegh \& Serpil, 2012), and for the selection of means of transport for logistic systems (Sokolova \& Chernov, 2016).

The advantages of applying IF ELECTRE is the most efficient modeling of hesitation and uncertainty of the decision maker, i.e. its reliability in relation to other methods that are sensitive to the confidence of the decision maker in the assessment. By applying IF ELECTRE, a comparison of alternatives can be achieved even in situations where there is no clear preference for one of the alternatives. The results clearly present the potential of suppliers, and the method provides insight into how preferential some suppliers are over others and vice versa.

The limitation of the application of this method is a very complex mathematical apparatus, which makes it difficult to apply. For a larger number of alternatives and criteria, i.e. a large number of input data, it is 
necessary to apply the method by programming in certain software packages. Other methods need to be used to determine the weights of the criteria because the IF ELECTRE method does not provide this possibility.

\section{Intuitive fuzzy number analysis}

The intuitive fuzzy number is suitable for modeling inaccurate data where the decision maker is unsure of the evaluation of a particular criterion, so that this uncertainty can be presented quantitatively.

The intuitive fuzzy set $\hat{A} u X=\{x\}$, (Atanassov, 1983: Atanassov, 1986) is represented by the following expression:

$$
\tilde{A}=\left\{x, \mu_{\tilde{A}}(x), v_{\tilde{A}}(x) \mid x \in X\right\}
$$

where: $\mu_{\tilde{A}}(x) \rightarrow[0,1]$ and $v_{\tilde{A}}(x) \rightarrow[0,1]$, and where the following condition applies: $0 \leq \mu_{\tilde{A}}(x)+v_{\tilde{A}}(x) \leq 1 \quad \forall x \in X$.

The value $\mu_{\tilde{A}}(x), v_{\tilde{A}}(x) \in[0,1]$ denote the degree of affiliation and the degree of non-affiliation $x$ for $\tilde{A}$.

For each intuitive fuzzy set $X$, valid: $\pi_{\tilde{A}}(x)=1-\mu_{\tilde{A}}(x)-v_{\tilde{A}}(x)$, where $\pi_{\tilde{A}}(x)$ is the intuitive index $x$ in $\tilde{A}$, that is, the degree of indecision.

The intuitive index $\pi_{\tilde{A}}(x)$ indicates the degree of indecision of decision makers in making an assessment.

For $\pi_{\tilde{A}}(x)$ the following conditions also apply: $0 \leq \pi_{\tilde{A}}(x) \leq 1 \quad \forall x \in X$,

as well as $\pi_{\tilde{A}}(x)=1-\mu_{\tilde{A}}(x)-\left[1-\mu_{\tilde{A}}(x)\right]=0 \quad \forall x \in X$ non-affiliation $x$ for $\tilde{A}$.

For intuitive fuzzy sets, it is important that they give the function of belonging and the function of non-belonging of a point at the same time $x$ in the fuzzy set $\tilde{A}$. 
The intuitive fuzzy set $\tilde{A}=\left\{x, \mu_{\tilde{A}}(x), v_{\tilde{A}}(x) \mid x \in X\right\}$ which belongs to the set of real numbers is called the intuitive fuzzy number if:

- there are at least two points $x_{0}, x_{1} \in X$ such that $\mu_{\tilde{A}}\left(x_{0}\right)=1$ and $v_{\tilde{A}}\left(x_{1}\right)=1$,

- affiliation function $\mu_{\tilde{A}}$ is fuzzy convex, and the function of nonaffiliation $v_{a}$ is fuzzy concave,

- $\mu_{\tilde{A}}$ is semi-continuous from above, and $v_{a}$ is semi-continuous from below,

- $\sup A=\left\{x \in X, v_{\tilde{A}}\left(x_{1}\right)<1\right\}$ is located in a confined space.

To compare the two intuitive fuzzy numbers (Chen, 2019), the following rules apply:

$A^{\prime}=\left(\mu_{a}, \vartheta_{a}, \pi_{a}\right)$ and $B^{\prime}=\left(\mu_{b}, \vartheta_{b}, \pi_{b}\right)$

1) $\mu_{a} \geq \mu_{b}$ and $\vartheta_{a} \leq \vartheta_{b}$, then $A \geq B$;

2) $\mu_{a}=\mu_{b}$ and $\vartheta_{a}=\vartheta_{b}$, then $A=B$;

$S_{a}=\mu_{a}-\vartheta_{a}$ and $H_{a}=\mu_{a}+\vartheta_{a}$

3) $S_{A}>S_{B}$, then $A>B$;

4) $S_{A}=S_{B}$ and $H_{A}=H_{B}$, then $A=B$;

5) $S_{A}=S_{B}$ and $H_{A} \leq H_{B}$, then $A \leq B$;

If $A^{\prime}$ and $B^{\prime}$ are intuitive fuzzy numbers, then the following rules apply (Atanassov, 1983): 
$A^{\prime}+B^{\prime}=\left\{\left(x, \mu_{a}(x)+\mu_{b}(x)-\mu_{a}(x) \times \mu_{b}(x), v_{a}(x) \times v_{b}(x) \mid x \in E\right\} ;\right.$

$A^{\prime}-B^{\prime}=\left\{\left(x, \min \left(\mu_{a}(x), v_{b}(x)\right), \max \left(v_{a}(x), \mu_{b}(x)\right) \mid x \in E\right\} ;\right.$

$A^{\prime} \otimes B^{\prime}=\left\{\left(x, \mu_{a}(x) \times \mu_{b}(x), v_{a}(x)+v_{b}(x)-v_{a}(x) \times v_{b}(x) \mid x \in E\right\} ;\right.$

$A^{\prime} \subset B^{\prime}, \forall x \in E, \mu_{a}(x) \leq \mu_{b}(x), v_{a}(x) \geq v_{b}(x)$;

$A^{\prime}=B^{\prime}, \forall x \in E, \mu_{a}(x)=\mu_{b}(x), v_{a}(x)=v_{b}(x)$;

$A^{\prime}: A^{c}=\left\{\left(x, v_{a}(x), \mu_{a}(x) \mid x \in E\right\}\right.$;

$A^{\prime} \cap B^{\prime}=\left\{\left(x, \min \left(\mu_{a}(x), \mu_{b}(x)\right), \max \left(v_{a}(x), v_{b}(x)\right) \mid x \in E\right\} ;\right.$

$A^{\prime} \cup B^{\prime}=\left\{\left(x, \max \left(\mu_{a}(x), \mu_{b}(x)\right), \min \left(v_{a}(x), v_{b}(x)\right) \mid x \in E\right\} ;\right.$

If two intuitive fuzzy sets are observed $\tilde{A}=\left\{x, \mu_{\tilde{A}}(x), v_{\tilde{A}}(x), \pi_{\tilde{A}}(x) \mid x \in X\right\}$ and $\tilde{B}=\left\{x, \mu_{\tilde{B}}(x), v_{\tilde{B}}(x), \pi_{\tilde{B}}(x) \mid x \in X\right\}$, where is $\Delta \mu_{i}=\mu_{\tilde{A}}\left(x_{i}\right)-\mu_{\tilde{B}}\left(x_{i}\right), \Delta v_{i}=v_{\tilde{A}}\left(x_{i}\right)-v_{\tilde{B}}\left(x_{i}\right)$ and $\Delta \pi_{i}=\pi_{\tilde{A}}\left(x_{i}\right)-\pi_{\tilde{B}}\left(x_{i}\right)$, the distance between two intuitive fuzzy sets can be calculated according to the following expressions given in Table 1.

Table 1 - An overview of how to determine the distance between two intuitive numbers Таблица 1 - Обзор способов определения расстояние между двумя интуитивно понятными числами

Табела 1 - Преглед начина одређивања дистанце између два интуитивна броја

\begin{tabular}{|l|l|}
\hline Author & Analytical expression \\
\hline $\begin{array}{l}\text { (Atanassov, } \\
1986)\end{array}$ & $\begin{array}{l}\text { Hamming } \\
\text { distance } \\
d_{h}(A, B)=\frac{1}{2} \times\left[\sum_{i=1}^{n}\left(\left|\mu_{a}\left(x_{i}\right)-\mu_{b}\left(x_{i}\right)\right|+\left|v_{a}\left(x_{i}\right)-v_{b}\left(x_{i}\right)\right|+\left|\pi_{a}\left(x_{i}\right)-\pi_{b}\left(x_{i}\right)\right|\right)\right] z a X=\left\{x_{1}, \ldots, x_{n}\right\}\end{array}$ \\
\hline $\begin{array}{l}\text { (Atanassov, } \\
\text { 1986) }\end{array}$ & $\begin{array}{l}\text { Normalization of Hamming distance } \\
d_{n-H}(A, B)=\frac{1}{2 n} \times\left[\sum_{i=1}^{n}\left(\left|\mu_{a}\left(x_{i}\right)-\mu_{b}\left(x_{i}\right)\right|+\left|v_{a}\left(x_{i}\right)-v_{b}\left(x_{i}\right)\right|+\left|\pi_{a}\left(x_{i}\right)-\pi_{b}\left(x_{i}\right)\right|\right)\right]\end{array}$ \\
\hline
\end{tabular}




\begin{tabular}{|c|c|}
\hline Author & Analytical expression \\
\hline $\begin{array}{l}\text { (Atanassov, } \\
1986)\end{array}$ & $\begin{array}{l}\text { Euclidean } \\
\text { distance } \\
d_{e}(A, B)=\sqrt{\frac{1}{2} \times\left[\sum_{i=1}^{n}\left(\mu_{a}\left(x_{i}\right)-\mu_{b}\left(x_{i}\right)\right)^{2}+\left(v_{a}\left(x_{i}\right)-v_{b}\left(x_{i}\right)\right)^{2}+\left(\pi_{a}\left(x_{i}\right)-\pi_{b}\left(x_{i}\right)\right)^{2}\right]}\end{array}$ \\
\hline $\begin{array}{l}\text { (Atanassov, } \\
1986)\end{array}$ & $\begin{array}{l}\text { Normalization of Euclidean distance } \\
d_{n-e}(A, B)=\sqrt{\frac{1}{2 n} \times\left[\sum_{i=1}^{n}\left(\mu_{a}\left(x_{i}\right)-\mu_{b}\left(x_{i}\right)\right)^{2}+\left(v_{a}\left(x_{i}\right)-v_{b}\left(x_{i}\right)\right)^{2}+\left(\pi_{a}\left(x_{i}\right)-\pi_{b}\left(x_{i}\right)\right)^{2}\right]}\end{array}$ \\
\hline $\begin{array}{l}\text { (Park et al, } \\
\text { 2013) }\end{array}$ & $D_{p}=1-\frac{1}{n} \sum_{i=1}^{n}\left|\Delta \pi_{i}\left(x_{i}\right)\right|$, where $\Delta \pi_{i}=\pi_{\tilde{A}}\left(x_{i}\right)-\pi_{\tilde{B}}\left(x_{i}\right)$ \\
\hline $\begin{array}{l}\text { (Chen, } \\
\text { 2016) }\end{array}$ & $\begin{array}{l}D(\tilde{A}, \tilde{B})=1-\frac{\left|2\left(\mu_{A}\left(x_{i}\right)-\mu_{B}\left(x_{i}\right)\right)-\left(v_{A}\left(x_{i}\right)-v_{B}\left(x_{i}\right)\right)\right|}{3} \times\left(1-\frac{\pi_{A}\left(x_{i}\right)-\pi_{B}\left(x_{i}\right)}{2}\right)- \\
\frac{\left|2\left(v_{A}\left(x_{i}\right)-v_{B}\left(x_{i}\right)\right)-\left(\mu_{A}\left(x_{i}\right)-\mu_{B}\left(x_{i}\right)\right)\right|}{3} \times\left(1-\frac{\pi_{B}\left(x_{i}\right)-\pi_{A}\left(x_{i}\right)}{2}\right)\end{array}$ \\
\hline $\begin{array}{l}\text { (Luo \& Ren, } \\
\text { 2016) }\end{array}$ & $\begin{array}{l}D(\tilde{A}, \tilde{B})=1-\frac{1}{3 n} \sum_{i=1}^{n}\left(\left|\mu_{A}^{2}\left(x_{i}\right)-\mu_{B}^{2}\left(x_{i}\right)\right|+\left|v_{A}^{2}\left(x_{i}\right)-v_{B}^{2}\left(x_{i}\right)\right|+\frac{\left|m_{A}^{2}\left(x_{i}\right)-m_{B}^{2}\left(x_{i}\right)\right|}{2}\right), \\
\text { where: } m_{A}\left(x_{i}\right)=\frac{\mu_{A}\left(x_{i}\right)+1-v_{A}\left(x_{i}\right)}{2}, \text { that } m_{B}\left(x_{i}\right)=\frac{\mu_{B}\left(x_{i}\right)+1-v_{B}\left(x_{i}\right)}{2} .\end{array}$ \\
\hline $\begin{array}{l}\text { (Zhang \& } \\
\mathrm{Fu}, 2006)\end{array}$ & $\begin{array}{l}D(\tilde{A}, \tilde{B})=1-\frac{1}{2 n} \sum_{i=1}^{n}\left(\left|\delta_{A}\left(x_{i}\right)-\delta_{B}\left(x_{i}\right)\right|+\left|\alpha_{A}\left(x_{i}\right)-\alpha_{B}\left(x_{i}\right)\right|\right), \\
\text { where: } \delta_{A}\left(x_{i}\right)=\mu_{A}\left(x_{i}\right)+\pi_{A}\left(x_{i}\right) \mu_{A}\left(x_{i}\right), \text { that } \delta_{B}\left(x_{i}\right)=\mu_{B}\left(x_{i}\right)+\pi_{B}\left(x_{i}\right) \mu_{B}\left(x_{i}\right) \\
\alpha_{A}\left(x_{i}\right)=v_{A}\left(x_{i}\right)+\pi_{A}\left(x_{i}\right) v_{A}\left(x_{i}\right), \text { that } \alpha_{B}\left(x_{i}\right)=v_{B}\left(x_{i}\right)+\pi_{B}\left(x_{i}\right) v_{B}\left(x_{i}\right)\end{array}$ \\
\hline
\end{tabular}

Analysis of the fuzzy Electre algorithm extended with an intuitive fuzzy number

There are a number of methods and approaches for ranking alternatives. In this paper, the multi-criteria model Electre (ÉLimination et Choix Traduisant la REalité) developed by Bernard Roy and his collaborators (Roy \& Bouyssou, 1986), is used. The ELECTRE method 
allows the decision maker to choose the best choice with maximum advantage and minimum conflicts in the function of different criteria, i.e. it clearly provides a picture of the value of each alternative. The method is based on pairwise comparisons of alternatives, which means that each alternative is compared with all other alternatives, based on which final recommendations can be made. The main advantage of this method is that it avoids compensation between the criteria and any normalization procedure, which distorts the original data. The method is based on pairwise comparisons of alternatives, which means: if the alternative "a" is better than the alternative "b" for most criteria and there is no criterion according to which the alternative "a" is strictly worse than the alternative "b", it can be said that the alternative "a" is better than the alternative "b".

This section presents the fuzzy Electre method extended with intuitive fuzzy numbers (Rouyendegh, 2018) and (Wu \& Chen, 2011). The algorithm of the extended method is further presented through six steps.

Step 1. Formation of a decision matrix, where the decision maker evaluates the alternatives according to all criteria. Grades are expressed using intuitive fuzzy numbers $X_{i j}=\left(\mu_{i j}, v_{i j}\right)$.

$$
X=\left[\begin{array}{cccc}
\left(\mu_{11}, v_{11}\right) & \left(\mu_{12}, v_{12}\right) & \ldots & \left(\mu_{1 n}, v_{1 n}\right) \\
\left(\mu_{11}, v_{11}\right) & \left(\mu_{22}, v_{22}\right) & \ldots & \left(\mu_{2 n}, v_{2 n}\right) \\
\left(\mu_{31}, v_{31}\right) & \left(\mu_{32}, v_{32}\right) & \ldots & \left(\mu_{3 n}, v_{3 n}\right) \\
\left(\mu_{m 1}, v_{m 1}\right) & \left(\mu_{m 2}, v_{m 2}\right) & \ldots & \left(\mu_{m n}, v_{m n}\right)
\end{array}\right]
$$

Step 2. Different methods can be used for determining the weight or importance of the criteria: usually the decision maker decides which method will determine the importance of each criterion, where the condition must be met so that: $\sum_{j=1}^{n} W_{j}=1$, where $0 \leq \omega_{j} \leq 1$.

Step 3. Defining sets:

A) consent $C_{k l}$ :

$$
\begin{aligned}
& C_{k l}=\left\{j \mid \mu_{k j} \geq \mu_{i j}, v_{k j}<v_{i j} i \pi_{k j}<\pi_{i j}\right\} \\
& C_{k l}^{\prime}=\left\{j \mid \mu_{k j} \geq \mu_{i j}, v_{k j}<v_{i j} i \pi_{k j} \geq \pi_{i j}\right\} \\
& C_{k l}^{\prime \prime}=\left\{j \mid \mu_{k j} \geq \mu_{i j}, v_{k j} \geq v_{i j}\right\}
\end{aligned}
$$


B) discrepancy $D_{k l}$ :

$$
\begin{aligned}
& D_{k l}=\left\{j \mid \mu_{k j}<\mu_{i j}, v_{k j} \geq v_{i j}, \pi_{k j} \geq \pi_{i j}\right\} \\
& D_{k l}^{\prime}=\left\{j \mid \mu_{k j}<\mu_{i j}, v_{k j} \geq v_{i j}, \pi_{k j}<\pi_{i j}\right\} \\
& D_{k l}^{\prime \prime}=\left\{j \mid \mu_{k j}<\mu_{i j}, v_{k j}<v_{i j}\right\}
\end{aligned}
$$

Step 4. Formation of the consent matrix $C_{p q}$ is the result of approvals and their weights; it is realized in accordance with the following:

$$
\begin{aligned}
& g_{k i}=\omega_{c} \times \sum_{j \in C_{k i}} \omega_{j}+\omega_{c}^{\prime} \times \sum_{j \in C_{k i}^{\prime}} \omega_{j}+\omega_{c}^{\prime \prime} \times \sum_{j \in C_{k i}^{\prime \prime}} \omega_{j} \\
& G=\left[\begin{array}{cccc}
- & g_{12} & \ldots & g_{1 m} \\
g_{21} & - & \ldots & g_{2 m} \\
g_{(m-1) 1} & \ldots & - & g_{(m-1) m} \\
g_{m 1} & g_{m 2} & g_{m(m-1)} & -
\end{array}\right]
\end{aligned}
$$

where $W^{\prime}=\left\{\omega_{c}, \omega_{c}^{\prime}, \omega_{c}^{\prime \prime}, \omega_{D}, \omega_{D}^{\prime}, \omega_{D}^{\prime \prime}\right\}$ is the relative importance of the criteria that decision makers can subjectively determine, so that the consent matrix can be written:

$$
K=\left[\begin{array}{cccc}
- & k_{12} & \ldots & k_{1 m} \\
k_{21} & - & \ldots & k_{2 m} \\
k_{(m-1) 1} & \ldots & - & k_{(m-1) m} \\
k_{m 1} & k_{m 2} & k_{m(m-1)} & -
\end{array}\right] \text { where } k_{k i}=g^{*}-g_{k i}
$$

$g^{*}$ is the maximum consensus index.

Step 5. Formation of the matrix of discrepancies $D_{p q}$ is the result of discrepancies and their weights, realized in accordance with the following

$$
\begin{aligned}
h_{k i} & =\frac{\max _{j \in D_{k i}} \omega_{D}^{*} \times d\left(X_{k j}, X_{i j}\right)}{\max _{j \in J} \times d\left(X_{k j}, X_{i j}\right)}, \omega_{D}^{*}=\left\{\omega_{d}, \omega_{D}^{\prime}, \omega_{D}^{\prime \prime}\right\} \\
H & =\left[\begin{array}{cccc}
- & h_{12} & \ldots & h_{1 m} \\
h_{21} & - & \ldots & h_{2 m} \\
h_{(m-1) 1} & \ldots & - & h_{(m-1) m} \\
h_{m 1} & h_{m 2} & h_{m(m-1)} & -
\end{array}\right]
\end{aligned}
$$


The discrepancy matrix is:

$$
\begin{aligned}
& L=\left[\begin{array}{cccc}
- & l_{12} & \ldots & l_{1 m} \\
l_{21} & - & \ldots & l_{2 m} \\
l_{(m-1) 1} & \ldots & - & l_{(m-1) m} \\
l_{m 1} & l_{m 2} & l_{m(m-1)} & -
\end{array}\right], \text { where } l_{k i}=h^{*}-h_{k i}, \\
& h^{*} \text { is the maximum discrepancy index. }
\end{aligned}
$$

Step 6. Forming a dominance matrix $\mathrm{R}$ which represents the aggregation of the safety matrix and the uncertainty matrix, and it has the following form:

$$
R=\left[\begin{array}{cccc}
- & r_{12} & \ldots & r_{1 m} \\
r_{21} & - & \ldots & r_{2 m} \\
r_{(m-1) 1} & \ldots & - & r_{(m-1) m} \\
r_{m 1} & r_{m 2} & r_{m(m-1)} & -
\end{array}\right] \text {, where } r_{k i}=\frac{l_{k i}}{k_{k i}+l_{k i}}
$$
following:

Ranking of alternatives is realized in accordance with the

$$
\bar{T}_{k i}=\frac{1}{m-1} \sum_{i=1, l \neq k}^{m} r_{k i}, k=1,2, \ldots ., m,
$$

where the best alternative is the one with the maximum value:

$$
A=\max \left\{\bar{T}_{k}\right\}
$$

\section{Defining criteria and linguistic qualifications}

When procuring funds, the decision maker is guided by the criteria that the asset should meet. The criteria are usually of technical and tactical nature. In most cases, the price criterion is taken into account when choosing a supplier. In this paper, the price criterion is not directly considered, bearing in mind that it indirectly influences the formation of other criteria that are interesting when it comes to the selection of suppliers of unmanned aircraft. It is known that in most papers, criteria of quantitative and qualitative nature are used. Quantitative criteria are easier to process, more understandable and acceptable to the decision maker, and as such cannot be changed. In this paper, the decision maker used criteria of a qualitative nature, which greatly complicates the decision-making process, given that qualitative evaluation criteria use linguistic variables. 
Defining linguistic variables is one of the first steps in forming a fuzzy model, so it is necessary to first name the linguistic variable, determine the number, shape and area of affiliation. According to (Tanasijević et al, 2007), there are no explicit recommendations on how to name the appropriate linguistic variables.

Linguistic variables are represented through linguistic expressions (small, medium, large, etc.) and linguistic values (moderate, very, about, more or less, conjunctions "and" and "or", etc.). Linguistic variables are words from natural language. In order for linguistic variables to be used as qualitative values in fuzzy logic, it is necessary to translate them in the fuzzy number which has its own domain, i.e. membership function.

Defining the domains of each fuzzy number is the task of the decision maker, so that it corresponds to the physical boundaries of the variable. If the variable is not of physical origin then the domain is defined on a set of real numbers belonging to a predetermined domain such as a standard scale of measures. The next parameter that is very important in modeling is granulation.

Granulation represents the number of fuzzy sets that describe uncertainty, i.e. the number of linguistic statements by which the considered uncertainty can be described in a sufficiently good way. It is recommended that a maximum of seven linguistic terms be commonly used (Lootsma, 1993), as the human brain can focus attention on a maximum of seven items at a time. Increasingly, problem-solving software writing tools, such as Matlab, are being used to solve problems.

In this paper, for the purposes of evaluating the criteria, the following linguistic expressions are defined, presented on the interval: very low $(\mathrm{VL})$ on the interval $[0,0.2]$; low $(\mathrm{L})$ at interval [0.2,0.4]; medium (eng. Medium - M) on the interval [0.4,0.6]; High $(\mathrm{H}-\mathrm{H})$ at interval $[0.6,0.8]$ and Very high $(\mathrm{VH})$ at interval $[0.8,1]$. The values on the interval are determined by the decision maker who gives evaluations based on his/her experience and expertise in the problem to be solved.

\section{Application of the proposed algorithm}

This section will show the application of the model for the selection of suppliers using an example of the procurement of an unmanned aircraft. To select the most suitable supplier, the fuzzy Electre method 
described above and extended by an intuitive fuzzy number is used. An intuitive fuzzy number is used to model the uncertainty and inaccuracy in the evaluation of the criteria. The importance of the criteria and the relative importance of the criteria are determined subjectively by the decision makers based on their knowledge, experience and their own assessments.

Six suppliers (suppliers from A1 to A6) applied for the tender. The decision makers selected four most important criteria in their opinion, such as: business $\left(\mathrm{K}_{1}\right)$, customer relations $\left(\mathrm{K}_{2}\right)$, technology $\left(\mathrm{K}_{3}\right)$ and logistics $\left(\mathrm{K}_{4}\right)$. The "business" criterion is assessed on the basis of the reputation, financial stability and management capacity of the supplier. The criterion of "customer relations" is observed through previous experiences, business references and ease of communication with the supplier. The criterion of "technology" is observed through capacity, the possibility of developing new products, improving existing products and the ability to solve problems. The criterion "logistics" is observed through delivery time, maintenance support, flexibility in changing orders, and reliability of delivery.

The decision maker determined the importance of $W=[w 1, w 2, w 3, w 4]$ for each criterion according to the following: business $w_{1}=0.1$, customer relations $w_{2}=0.2$, technology $w_{3}=0.3$, and logistics $w_{4}=0.4$,

as well as the relative importance of the criterion $W^{\prime}=[w c, w c ', w c ~ ", w d$, wd ', wd"] in accordance with the following $W^{\prime}=[1,0.66,0.33,1,0.66,0.33]$.

Determining the evaluation of each criterion observed for each alternative (supplier) is based on knowledge, experience and assessment of decision makers. Grades are modeled by an intuitive fuzzy number $\tilde{A}=\left(\mu_{i}, \vartheta_{i}, \pi_{i}\right)$ and presented at intervals $0 \leq \mu_{i} \leq 1,0 \leq \vartheta_{i} \leq 1,0 \leq \pi_{i} \leq 1$.

Based on the collected data and research, the decision maker evaluated all alternatives according to all criteria and presented the results in Table 2. 
Table 2 - Decision matrix modeled by intuitive fuzzy numbers

Таблица 2 - Матрица решений, смоделированная интуитивно понятными фраззичислами

Табела 2 - Матрица одлучивања моделована интуитивним фрази бројевима

\begin{tabular}{|c|c|c|c|c|c|c|c|c|c|c|c|c|}
\hline $\mathrm{K}$ & \multicolumn{3}{|c|}{ K1 } & \multicolumn{3}{|c|}{$\mathrm{K} 2$} & \multicolumn{3}{|c|}{ K3 } & \multicolumn{3}{|c|}{ K4 } \\
\hline$A$ & $\mu_{i}$ & $v_{i}$ & $\pi_{i}$ & $\mu_{i}$ & $v_{i}$ & $\Pi_{i}$ & $\mu_{i}$ & $v_{i}$ & $\Pi_{i}$ & $\mu_{i}$ & $v_{i}$ & $\Pi_{i}$ \\
\hline $\mathrm{A} 1$ & 0.23 & 0.587 & 0.183 & 0.61 & 0.2 & 0.19 & 0.192 & 0.63 & 0.178 & 0.75 & 0.15 & 0.1 \\
\hline A2 & 0.33 & 0.554 & 0.116 & 0.25 & 0.61 & 0.14 & 0.63 & 0.192 & 0.178 & 0.0984 & 0.45 & 0.452 \\
\hline A3 & 0.3 & 0.197 & 0.503 & 0.45 & 0.36 & 0.19 & 0.259 & 0.56 & 0.181 & 0.31 & 0.66 & 0.03 \\
\hline A4 & 0.37 & 0.62 & 0.01 & 0.36 & 0.45 & 0.19 & 0.337 & 0.484 & 0.179 & 0.15 & 0.82 & 0.03 \\
\hline A5 & 0.38 & 0.2 & 0.42 & 0.29 & 0.39 & 0.32 & 0.32 & 0.35 & 0.33 & 0.5 & 0.25 & 0.25 \\
\hline A6 & 0.259 & 0.56 & 0.181 & 0.24 & 0.35 & 0.41 & 0.3 & 0.28 & 0.42 & 0.45 & 0.28 & 0.27 \\
\hline
\end{tabular}

Following the steps applied in the fuzzy Electre method extended by an intuitive fuzzy number, the following results are obtained:

a) Results of the obtained consent conditions $C_{k l}$ and the noncompliance conditions $D_{k l}$ based on expressions (5) and (6)

b)

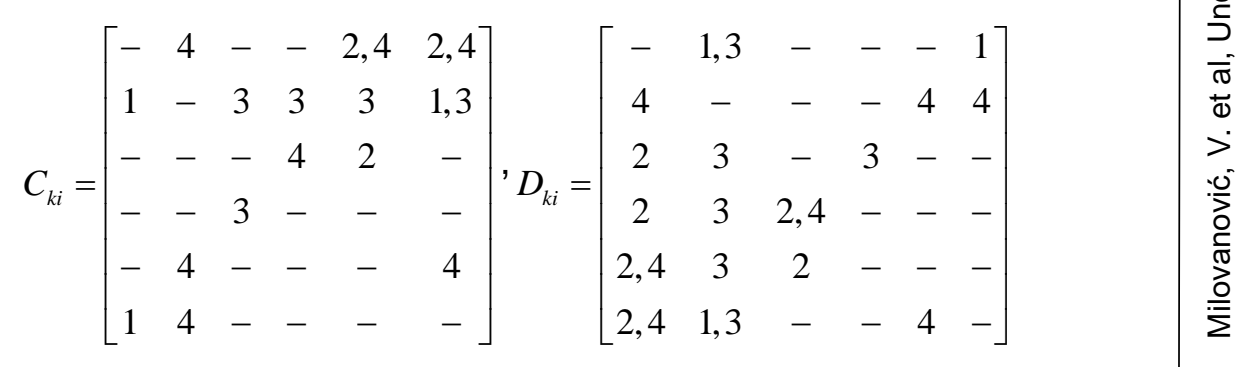

$$
C_{k i}^{\prime}=\left[\begin{array}{cccccc}
- & 2 & 2,4 & 2,4 & - & - \\
3 & - & - & - & - & - \\
1,3 & 2 & - & 2 & - & 1 \\
3 & 2 & - & - & - & - \\
1,3 & 1,2 & 3,4 & 1,4 & - & 1 \\
3 & - & 3,4 & 4 & - & -
\end{array}\right], \quad D_{k i}^{\prime}=\left[\begin{array}{cccccc}
- & - & 1,3 & 3 & 1,3 & 3 \\
2 & - & 2 & 2 & 1,2 & - \\
4 & - & - & - & 3,4 & 3,4 \\
4 & - & - & - & 1,4 & 4 \\
- & - & - & - & - & - \\
- & - & 1 & - & 1 & -
\end{array}\right]
$$




$$
C_{k i}^{\prime \prime}=\left[\begin{array}{cccccc}
- & - & - & - & - & - \\
- & - & 1 & - & - & 2 \\
- & 4 & - & - & - & 2 \\
1 & 1,4 & 1 & - & 2,3 & 1,2,3 \\
- & - & 1 & - & - & 2,3 \\
- & - & - & - & - & -
\end{array}\right], \quad D_{k i}^{\prime \prime}=\left[\begin{array}{cccccc}
- & - & - & 1 & - & - \\
- & - & 4 & 1,4 & - & - \\
- & 1 & - & 1 & 1 & - \\
- & - & - & - & - & - \\
- & - & - & 2,3 & - & - \\
- & 2 & 2 & 1,2,3 & 2,3 & -
\end{array}\right]
$$

c) Results of the obtained own consent "G" based on expression (7):

$$
G=\left[\begin{array}{cccccc}
- & 0.5332 & 0.3996 & 0.3996 & 0.6 & 0.6 \\
0.2998 & - & 0.3333 & 0.3 & 0.3 & 0.4666 \\
0.2664 & 0.2664 & - & 0.5332 & 0.2 & 0.1332 \\
0.2331 & 0.2997 & 0.3333 & - & 0.1665 & 0.1998 \\
0.2664 & 0.5998 & 0.4995 & 0.333 & - & 0.6331 \\
0.2998 & 0.4 & 0.4662 & 0.2664 & 0 & -
\end{array}\right]
$$

Results of the obtained own disagreement " $\mathrm{H}$ " based on expression (8):

$$
H=\left[\begin{array}{cccccc}
- & 0.25587 & 0.49638 & 0.15055 & 0.66 & 0.63561 \\
1 & - & 0.40553 & 0.33 & 1 & 1 \\
0.66 & 0.99089 & - & 0.33 & 0.66 & 0.63802 \\
0.66 & 0.73435 & 0.34632 & - & 0.66 & 0.66 \\
0.82479 & 0.77196 & 0.27357 & 0.09495 & - & 0 \\
1 & 0.97186 & 0.66 & 0.1583 & 0.66 & -
\end{array}\right]
$$

d) Results of the obtained consent "K" based on expression (9):

$$
K=\left[\begin{array}{cccccc}
- & 0.0999 & 0.2335 & 0.2335 & 0.0331 & 0.0331 \\
0.3333 & - & 0.2998 & 0.3331 & 0.3331 & 0.1665 \\
0.3667 & 0.3667 & - & 0.0999 & 0.4331 & 0.4999 \\
0.4 & 0.3334 & 0.2998 & - & 0.4666 & 0.4333 \\
0.3667 & 0.0333 & 0.1336 & 0.3001 & - & 0 \\
0.3333 & 0.2331 & 0.1669 & 0.3667 & 0.6331 & -
\end{array}\right]
$$

e) Results of the obtained discrepancy "L" based on expression (10): 


$$
L=\left[\begin{array}{cccccc}
- & 0.7441 & 0.5036 & 0.8495 & 0.34 & 0.3644 \\
0 & - & 0.5945 & 0.67 & 0 & 0 \\
0.34 & 0.0091 & - & 0.67 & 0.34 & 0.362 \\
0.34 & 0.2657 & 0.6537 & - & 0.34 & 0.34 \\
0.1752 & 0.228 & 0.7264 & 0.905 & - & 1 \\
0 & 0.0281 & 0.34 & 0.8417 & 0.34 & -
\end{array}\right]
$$

f) Results of the obtained domination "R" based on expression (11):

$$
R=\left[\begin{array}{cccccc}
- & 0.8816 & 0.6832 & 0.7844 & 0.9113 & 0.9167 \\
0 & - & 0.6648 & 0.6679 & 0 & 0 \\
0.4811 & 0.0242 & - & 0.8702 & 0.4398 & 0.42 \\
0.4595 & 0.4435 & 0.6856 & - & 0.4215 & 0.4397 \\
0.3233 & 0.8726 & 0.8447 & 0.7510 & - & 1 \\
0 & 0.1077 & 0.6707 & 0.6965 & 0.3494 & -
\end{array}\right]
$$

g) Ranking of the obtained alternatives, based on expressions (12) and (13), Table 3:

Table 3-Review of the obtained results Таблица 3 - Обзор полученных результатов Табела 3 - Преглед добијених резултата

\begin{tabular}{|c|c|c|c|}
\hline & Value & Alternative & Rank \\
\hline$T_{1}$ & 0.8355 & $\mathrm{~A}_{1}$ & 1 \\
\hline $\mathrm{T}_{2}$ & 0.2665 & $\mathrm{~A}_{2}$ & 6 \\
\hline $\mathrm{T}_{3}$ & 0.4471 & $\mathrm{~A}_{3}$ & 4 \\
\hline $\mathrm{T}_{4}$ & 0.4899 & $\mathrm{~A}_{4}$ & 3 \\
\hline $\mathrm{T}_{5}$ & 0.7583 & $\mathrm{~A}_{5}$ & 2 \\
\hline $\mathrm{T}_{6}$ & 0.3649 & $\mathrm{~A}_{6}$ & 5 \\
\hline
\end{tabular}

The final obtained results showed that the best ranked alternative is $A_{1}$, i.e. the worst ranked alternative is $A_{2}$. The alternative $A_{5}$ is, in the decision-maker's opinion, extremely close to the alternative $A_{1}$, which gives the possibility that the alternative $A_{5}$ could compete for the 
purchase of an unmanned aircraft. The alternatives $A_{2}$ and $A_{6}$ do not meet the required criteria because their value is extremely low, so their further role in procurement is not to be considered. The alternatives $A_{3}$ and $A_{4}$ are also not shortlisted for the procurement of an unmanned aircraft, but in the next procurement they could apply if they work on improving the set criteria. The decision maker specifically focused on the criterion of "logistics" because the assumption is that all other criteria indirectly affect the criterion of "logistics", such as: price, warranty, delivery time, and technical documentation.

\section{Conclusion}

In this paper, one of the methods to model uncertainty using intuitive fuzzy numbers is presented. Bearing in mind that the evaluation criteria are of qualitative nature, it automatically implies that the evaluation is realized based on linguistic qualifications. The use of linguistic qualifications by nature generates a problem of subjectivity in assessment. In order to solve or reduce this problem, intuitive fuzzy numbers are proposed in this paper. The analysis of the literature cited in the paper showed that modeling by using intuitive fuzzy numbers reduces the inaccuracy, indecision and hesitation of the decision maker when evaluating the offered options.

The criteria based on which the alternatives were evaluated were proposed from the point of view of logistic support. In relation to a large number of random works, the criterion of price and costs is excluded, because when one looks at the proposed criteria, it could be seen that they indirectly affect them. In the paper, intuitive fuzzy numbers are presented at intervals from 0 to 1 , with specific domains for each linguistic qualification.

To select the most favorable option, a multicriteria fuzzy ELECTRE model extended with an intuitive fuzzy number (IF ELECTRE) is proposed in the paper. The reason is that it gives the decision maker the opportunity to choose the best choice with maximum advantage and minimum conflicts as a function of different criteria, which clearly provides a picture of the value of each alternative, or preference between alternatives.

The models and algorithms applied in selecting the most favorable option (supplier) for an unmanned aircraft clearly show the differences between suppliers, which can help the decision maker in future procurement. The options $A_{2}$ and $A_{6}$ showed a low value in terms of 
references and previous experience, which is guidance to the decision maker not to consider them in future procurement.

It can be concluded that such a model of combined models and algorithms can be used in selecting the most favorable supplier because it clearly shows the differences between all options, as well as their values. Indecision and hesitation in assessment are minimized by applying an intuitive approach.

Depending on the problem to be solved, there is a need to generate hybrid models to make the best use of them in practice. In further research, it is necessary to use other methods to determine the weight of the criteria, such as the Best-Worst method, AHP and other methods extended with intuitive fuzzy numbers. It is also necessary to use other methods of multicriteria decision making extended by intuitive fuzzy numbers to compare alternatives. It is necessary to compare the obtained results and suggest the alternatives that are best ranked, and to suggest the used models for solving similar problems.

\section{References}

Alipour, M., Hafezi, R., Ervural, B., Kaviani, M.A. \& Kabak, Ö. 2018. Longterm policy evaluation: Application of a new robust decision framework for Iran's energy exports security. Energy, 157, pp.914-931. Available at: https://doi.org/10.1016/j.energy.2018.05.176.

Arunodaya, R.M., Abhishek, K.G., Honey, P., Pushpendra, R., Huchang, L. \& Abbas, M. 2020. An Extended Intuitionistic Fuzzy Multi-Attributive Border Approximation Area Comparison Approach for Smartphone Selection Using Discrimination Measures. Informatica, 32(1), pp.119-143, Available at: https://doi.org/10.15388/20-infor430.

Atanassov, K.T. 1983. Intuitionistic Fuzzy Sets, VII ITKR Session, Sofia, 20-23 June. Deposed in Centr. Sci.-Techn. Library of the Bulg. Acad. of Sci., 1697/84) (in Bulgarian). Reprinted: Int. J. Bioautomation, 2016, 20(S1), S1-S6 [online].

Available

at: https://www.proquest.com/openview/488e821e83b74821060562dc9b20f49e/1 ?p q-origsite $=$ gscholar\&cbl=4720765 [Accessed: 20 July 2021].

Atanassov, K.T. 1986. Intuitionistic fuzzy sets. Fuzzy sets and Systems, 20(1), pp.87-96. Available at: https://doi.org/10.1016/S01650114(86)80034-3.

Chen, T-Y. 2016. An IVIF-ELECTRE outranking method for multiple criteria decision-making with interval-valued intuitionistic fuzzy sets. Technological and Economic Development of Economy, 22(3), pp.416-452. Available at: https://doi.org/10.3846/20294913.2015.1072751. 
Chen, T-Y. 2019. A novel PROMETHEE-based method using a Pythagorean fuzzy combinative distance-based precedence approach to multiple criteria decision making. Applied Soft Computing, 82(at.number:105560). Available at: https://doi.org/10.1016/j.asoc.2019.105560.

Das, S., Kar, S. \& Pal, T. 2017. Robust decision making using intuitionistic fuzzy numbers. Granular Computing, 2(1), pp.41-54. Available at: https://doi.org/10.1007/s41066-016-0024-3.

Dubois, D. \& Prade, H. 1978. Operations on fuzzy numbers. International Journal of Systems Science, 9(6), pp.613-626. Available at: https://doi.org/10.1080/00207727808941724.

Dubois, D. \& Prade, H. 1979. Operations in a fuzzy-valued logic. Information and Control, 43(2), pp.224-240. Available at https://doi.org/10.1016/S0019-9958(79)90730-7.

Goker, N.A. 2021. A novel integrated intuitionistic fuzzy decision aid for agile outsourcing provider selection: a COVID-19 pandemic-based scenario analysis. Soft Computing. Available at: https://doi.org/10.1007/s00500-021-06037-0.

Jacek, Ż. \& Kruszyński, M. 2015. Application of AHP and ELECTRE III/IV Methods to Multiple Level, Multiple Criteria Evaluation of Urban Transportation Projects. Transportation Research Procedia, 10, pp.820-830. Available at: https://doi.org/10.1016/j.trpro.2015.09.035.

Kaur, P. 2014. Selection of Vendor Based on Intuitionistic Fuzzy Analytical Hierarchy Process. Advances in Operations Research, 2014(art.ID:987690). Available at: https://doi.org/10.1155/2014/987690.

Komsiyah, S., Wongso, R. \& Pratiwi, S.W. 2019. Applications of the Fuzzy ELECTRE Method for Decision Support Systems of Cement Vendor Selection. Procedia Computer Science, 157, pp.479-488. Available at: https://doi.org/10.1016/j.procs.2019.09.003.

Kushwaha, D.K., Panchal, D. \& Sachdeva, A. 2020. Risk analysis of cutting system under intuitionistic fuzzy environment. Reports in Mechanical Engineering, 1(1), pp.162-173 [online].

Available

at: https://www.frontpres.rabek.org/index.php/asd/article/view/21 [Accessed: 20 July 2021].

Lootsma, A.F. 1993. Scale sensitivity in the multiplicative AHP and SMART. Journal of Multi-Criteria Decision Analysis, 2(2), pp.87-110 Available at:https://doi.org/10.1002/mcda.4020020205.

Luo, L. \& Ren, H. 2016. A new similarity measure of intuitionistic fuzzy set and application in madm problem. AMSE JOURNALS-2016-Series: Advances A, 59(1), pp.204-223 [online]. Available at: https://amsemodelling.com/publications/advances_in_modelling/General_Mathe matics/531/A\%20New\%20Similarity\%20Measure $\% 20$ of\%20Intuitionistic $\% 20 \mathrm{Fuz}$ zy\%20Set\%20and\%20Application\%20in\%20MADM\%20Problem.pdf [Accessed: 20 July 2021].

Mendel, J.M. 2003. Type-2 Fuzzy Sets: Some Questions and Answers. IEEE Connections, Newsletter of the IEEE Neural Networks Society, 1, pp.10-13 [online].

Available 
http://150.214.190.154/sites/default/files/files/linksInterest/Tutorials/Tutorial-

Mendel-Type-2-Fuzzy-Sets.pdf [Accessed: 20 July 2021].

Milošević, T.D., Pamučar, D.S. \& Prasenjit, C. 2021. Model for selecting a route for the transport of hazardous materials using a fuzzy logic system. Vojnotehnički glasnik/Military Technical Courier, 69(2), pp.355-390. Available at: https://doi.org/10.5937/vojtehg69-29629.

Nirmala, G. \& Uthra, G. 2017. Triangular intuitionistic fuzzy ahp and its application to select best product of notebook computer. International Journal of Pure and Applied Mathematics, 113(10), pp.253-261 [online]. Available at: http://acadpubl.eu/jsi/2017-113-pp/articles/10/28.pdf [Accessed: 20 July 2021].

Park, J-H., Hwang, J-H., Park, W-J., Wei, H. \& Lee, S-H. 2013. Similarity measure on intuitionistic fuzzy sets. Journal of Central South University, 20, pp.2233-2238. Available at: https://doi.org/10.1007/s11771-013-1729-y.

Pokorni, S. 2021. Current state of the application of artificial intelligence in reliability and maintenance. Vojnotehnički glasnik/Military Technical Courier, 69(3), pp.578-593. Available at: https://doi.org/10.5937/vojtehg69-30434.

Rogulj, K. \& Kilić Pamuković, J. 2021. Environmental Adaptation of Construction Barriers under Intuitionistic Fuzzy Theory. Technical Journal 15(1), pp.1-10. Available at: https://doi.org/10.31803/tg-20210215210742.

Rouyendegh, B.D. 2018. The Intuitionistic Fuzzy ELECTRE model. International Journal of Management Science and Engineering Management, 13(2), pp.139-145. Available at: https://doi.org/10.1080/17509653.2017.1349625.

Rouyendegh, B.D. \& Serpil, E. 2012. Selecting the Best Project Using the Fuzzy ELECTRE Method. Mathematical Problems in Engineering, 2012(art.ID:790142). Available at: https://doi.org/10.1155/2012/790142.

Roy, B. \& Bouyssou, D. 1995. Comparison of Two Decision-Aid Models Applied to a Nuclear Power Plant Siting Example. In: Munier, B.R. (eds) Markets, Risk and Money. Theory and Decision Library (Series B: Mathematical and Statistical Methods), 26. Springer, Dordrecht. Available at: https://doi.org/10.1007/978-94-011-0780-8_13.

Shureshjani, R.A. 2021. A developed Best-Worst method to solve multicriteria decision-making problems under intuitionistic fuzzy environments. Mathematics and Computational Sciences, 1(4), pp.43-55. Available at: https://doi.org/10.30511/mcs.2021.537067.1033.

Sokolova, M.L. \& Chernov, V.G. 2016. Choice of the means of transport for the creation of a logistic system relying on uncertainties. Vojnotehnički glasnik/Military Technical Courier, 64(2), pp.431-446. Available at: https://doi.org/10.5937/vojtehg64-10304.

Šmidovnik, T. \& Grošelj, P. 2021. Inclusion of uncertainty with different types of fuzzy numbers into DEMATEL. Serbian Journal of Management, 16(1), pp.49-59. Available at: https://doi.org/10.5937/sjm16-30160.

Tanasijević, M., Ivezić, D. \& Ivković, S. 2007. Model for analysis and synthesis of dependability performance. Journal of Applied Engineering Science, 5(17), pp.15-24 [online]. Available at: 
http://www.engineeringscience.rs/article/2007/Volume_5_17/Volume_5_article_1 08 (in Serbian [Accessed: 20 July 2021].

Tavana, M., Zareinejad, M., Di Caprio, D. \& Kaviani, M.A. 2016. An integrated intuitionistic fuzzy AHP and SWOT. Applied Soft Computing, 40, pp.544-557. Available at: https://doi.org/10.1016/j.asoc.2015.12.005.

Wu, M-C. \& Chen, T-Y. 2011. The ELECTRE Multicriteria Analysis Approach Based on Atanassov's Intuitionistic Fuzzy Sets. Expert Systems with Applications, 38(10), pp.12318-12327. Available at: https://doi.org/10.1016/j.eswa.2011.04.010.

Zadeh, L.A. 1965. Fuzzy sets. Information and Control. Information Sciences, 8(3), pp.338-353. Available at: https://doi.org/10.1016/S00199958(65)90241-X.

Zadeh, L.A. 1975a. The concept of a linguistic variable and its application to approximate reasoning-I. Information Sciences, 8(3), pp.199-249. Available at: https://doi.org/10.1016/0020-0255(75)90036-5.

Zadeh, L.A. 1975b. The concept of a linguistic variable and its application to approximate reasoning-II. Information Sciences, 8(4), pp.301-357. Available at: https://doi.org/10.1016/0020-0255(75)90046-8.

Zadeh, L.A. 2011. A note on Z-numbers. Information Sciences, 181(14), pp.2923-2932. Available at: https://doi.org/10.1016/j.ins.2011.02.022.

Zeng, X-T., Li, D-F. \& Yu, G-F. 2014. A Value and Ambiguity-Based Ranking Method of Trapezoidal Intuitionistic Fuzzy Numbers and Application to Decision Making. The Scientific World Journal, 2014(art.ID:560582). Available at: https://doi.org/10.1155/2014/560582.

Zhang, C. \& Fu, H. 2006. Similarity measures on three kinds of fuzzy sets. Pattern Recognition Letters, 27(12), pp.1307-1317. Available at: https://doi.org/10.1016/j.patrec.2005.11.020.

Zheng, P., Xu, X. \& Xie, S.Q. 2019. A weighted interval rough number based method to determine relative importance ratings of customer requirements in QFD product planning. Journal of Intelligent Manufacturing, 30, pp.3-16. Available at: https://doi.org/10.1007/s10845-016-1224-z.

Zimmermann, H-J. 1996. Fuzzy set theory and its applications, Boston, Kluwer Academic Publiching, USA. Available at: https://doi.org/10.1007/978-94010-0646-0. ISBN: 978-94-010-0646-0.

\section{МОДЕЛИРОВАНИЕ НЕОПРЕДЕЛЕННОСТИ С ПОМОЩЬЮ ИНТУИЦИОНИСТСКИХ НЕЧЕТКИХ ЧИСЕЛ}

\footnotetext{
Владимир Р. Милованович ${ }^{a}$, корреспондент, Александар В. Алексичб, Влада С. Соколович ${ }^{a}$, Марьян А. Миленков ${ }^{a}$,

а Университет обороны в г. Белград, Военная академия, кафедра логистики, г. Белград, Республика Сербия,

${ }^{6}$ Крагуевацкий университет, факультет инженерных наук, кафредра технологии машиностроения, г. Крагуевац, Республика Сербия
} 
РУБРИКА ГРНТИ: 27.00.00 МАТЕМАТИКА:

27.47.00 Математическая кибернетика;

27.47.19 Исследование операций,

80.00.00 ПРОЧИЕ ОТРАСЛИ ЭКОНОМИКИ:

81.88.00 Материально-техническое снабжение. Логистика

ВИД СТАТЬИ: оригинальная научная статья

Резюме:

Введение/цель: В статье обсуждается выбор наиболее оптимального поставщика на примере беспилотного летательного аппарата, в тех случаях, когда ответственное лицо, принимающее решение, владеет данными качественного характера. Проблемы, возникающие на практике при выборе поставщиков, связаны с выбором соответствующих критериев, а также с тем, как они оцениваются лицом, принимающим решения. Одним из способов оценки критериев качественного характера является использование лингвистических средств, предоставляющих лицам, принимающим решения, свободу выражать свою позицию и мнение методом описательной оценки. Так как данный метод оценки не самый точный, он может внести неопределенность при принятии решения.

Методы: Для решения проблемы неопределенности в данной статье предлагается метод моделирования данных $c$ использованием интуитивно понятных фраззи-чисел. Интуитивно понятные фраззи-числа приемлемы для решения проблемы неопределенности в ситуациях, когда необходимо проанализировать безопасность оценивания. Для ранжирования поставщиков используется метод ELECTRE, адаптированный к интуитивно понятным фраззи-числам (IF ELECTRE). Memod IF ELECTRE был выбран благодаря его четкости в представлении потенциала всех поставщиков, то есть их преимуществ и недостатков по отношению к требуемым критериям.

Результаты: Используя IF ELECTRE, конечные результаты демонстрируют взаимное предпочтение или безразличие между поставщиками. Ранжирование четко выявляет потенциал всех поставщиков, который в будущих закупках может послужить ориентиром при принятии решений.

Выводы: Научный вклад данной статьи заключается в предложенной модели, которая может применяться на практике для решения не только проблемы выбора поставщика, но и аналогичных задач, решение которых принимается на 


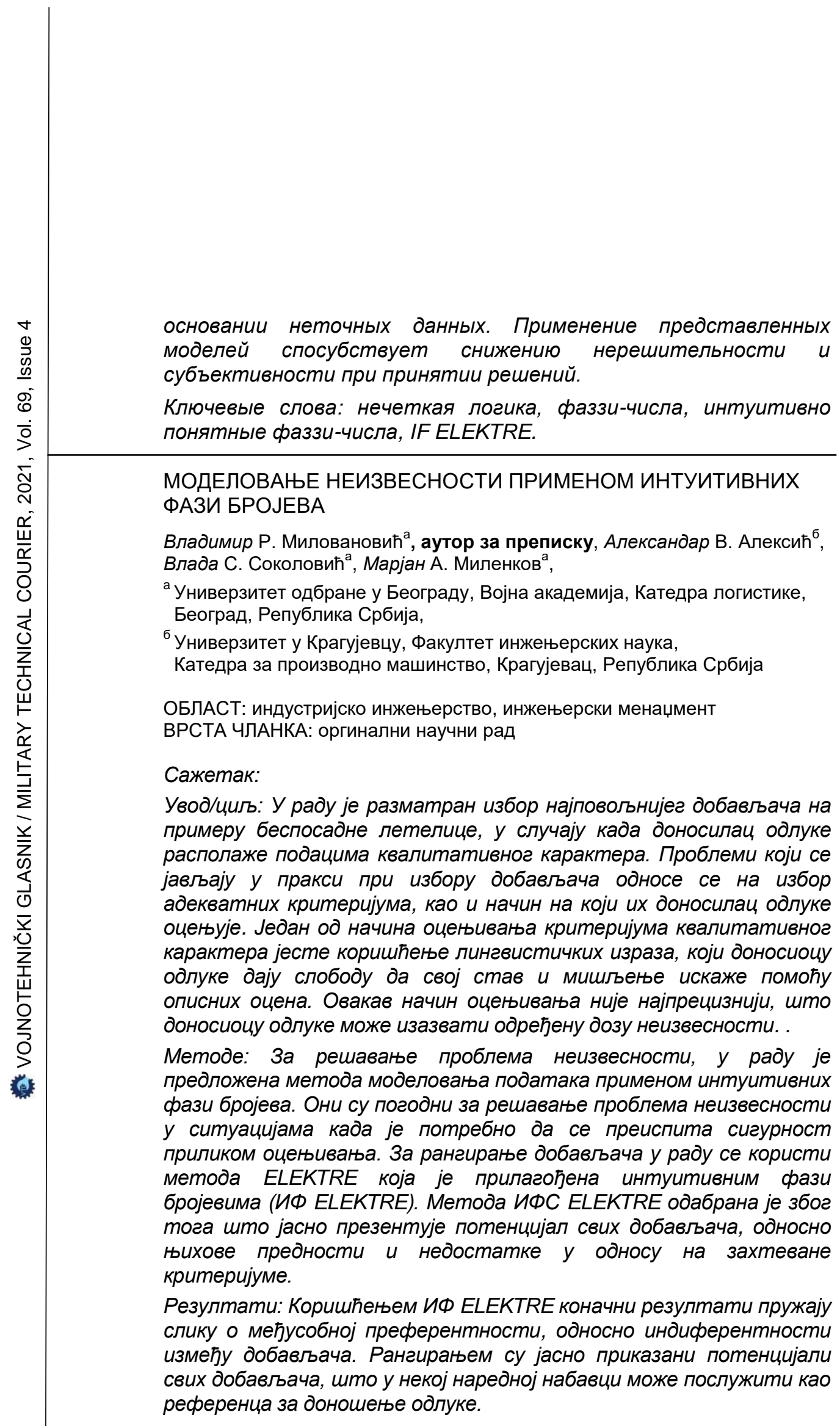


Закључак: Допринос овог рада огледа се у предложеном моделу који у пракси може послужити за решавање проблема избора добављача, али и сличних проблема када се одлука доноси на основу непрецизних података. Коришћењем наведених модела смањује се неодлучност и субјективност при доношењу одлуке.

Кључне речи: фрази логика, фази број, интуитивни фрази број, ИФ ELEKTRE.

Paper received on / Дата получения работы / Датум пријема чланка: 26.07.2020. Manuscript corrections submitted on / Дата получения исправленной версии работы / Датум достављања исправки рукописа: 07.10.2020.

Paper accepted for publishing on / Дата окончательного согласования работы / Датум коначног прихватања чланка за објављивање: 09.10.2020.

(C) 2021 The Authors. Published by Vojnotehnički glasnik / Military Technical Courier (www.vtg.mod.gov.rs, втг.мо.упр.срб). This article is an open access article distributed under the terms and conditions of the Creative Commons Attribution license (http://creativecommons.org/licenses/by/3.0/rs/).

(c) 2021 Авторы. Опубликовано в «Военно-технический вестник / Vojnotehnički glasnik / Military Technical Courier» (www.vtg.mod.gov.rs, втг.мо.упр.срб). Данная статья в открытом доступе и распространяется в соответствии с лицензией «Creative Commons» (http://creativecommons.org/licenses/by/3.0/rs/).

(C) 2021 Аутори. Објавио Војнотехнички гласник / Vojnotehnički glasnik / Military Technical Courier (www.vtg.mod.gov.rs, втг.мо.упр.срб). Ово је чланак отвореног приступа и дистрибуира се у складу са Creative Commons licencom (http://creativecommons.org/licenses/by/3.0/rs/). 